\title{
Pulmonary Clearance of Staphylococcus Aureus and Plasma Angiotensin-Converting Enzyme Activity in Hydrocarbon Pneumonitis
}

\author{
LUAY A. NOURI, ${ }^{(6)}$ DANIEL O. SORDELLI, M. CRISTINA CERQUETTI, JUAN M. SAAVEDRA, \\ ANNE MORRIS HOOKE, JOSEPH A. BELLANTI \\ The International Center for Interdisciplinary Studies of Immunology, Georgetown University School of Medicine and \\ Dentistry, Washington, D.C., and Section of Pharmacology, Laboratory of Clinical Sciences, National Institute of \\ Mental Health, NIH, Bethesda, Maryland, USA
}

\begin{abstract}
Summary
Pulmonary clearance of Staphylococcus aureus and plasma angiotensin-converting enzyme (ACE) activity were investigated in an experimental mouse model of kerosene aspiration. Twenty-four hours after acute kerosene aspiration, mice were exposed for $\mathbf{3 0}$ min to an aerosol containing the pathogen, and the uncleared bacteria ratio (UBR) determined $4 \mathrm{~h}$ after nebulization. The results showed a significant increase $(P=0.004)$ in UBR in animals with severe pneumonitis $(0.44 \pm 0.05)$ when compared with controls $(0.24 \pm 0.03)$. This impairment in lung clearance correlated with the increase in lung weight and the decrease in plasma ACE levels. Mice with kerosene pneumonitis had zones of lung injury, and areas with no gross signs of tissue damage. Lung clearance of $S$. aureus was significantly impaired in damaged areas whereas it was no different from controls in the non-affected areas. It is suggested that the measurement of plasma ACE activity may be an adjunct in the assessment of the extent of lung injury in hydrocarbon aspiration in children.
\end{abstract}

\section{Abbreviations}

ACE, angiotensin-converting enzyme

Bw, body weight

cfu, colony forming units

Lw, lung weight

UBR, uncleared bacteria ratio

Poisoning of young children with petroleum distillate products continues to be a serious hazard all over the world, including the most developed countries $(1,5,7,9,11,34,37,38,39,40,42,43$, $54,55)$. In the United States during the period 1968-78, there was an average of more than 3500 children under 5 years of age who ingested petroleum products, reported to the National Clearinghouse for Poison Control Centers. This figure represents $5-10 \%$ of the actual ingestions $(17,18)$; therefore, it is reasonable to predict that $17,500-35,000$ cases of ingestion of petroleum products occur each year. The most commonly ingested products are kerosene and furniture polishes, which often contain mineral seal oil, or naphtha $(21,42,58)$.

In addition to the depression of the central nervous system, hydrocarbons induce a serious acute chemical pneumonitis that occurs in $38-87 \%$ of the hydrocarbon intoxicated patients $(5,42)$. This pneumonitis may become complicated by secondary bacterial or viral infection as suggested by most workers $(1,5,10,52,53)$, but doubted by others $(4,51,59)$. Burley and Huber in 1971 (6) demonstrated diminished bacterial clearance from murine lungs after kerosene ingestion. Pathologic changes in the lungs include edema and damage to pulmonary blood vessels in animals $(3,12$, $15,20,29,36,44)$ and man $(14,49,50)$. Plasma ACE activity has been proposed as an indicator of lung tissue damage (28) because pathologic conditions effecting changes in vascular permeability cause the release of the enzyme from the endothelium of pulmonary blood vessels. Animal studies have shown that intraperitoneal injection of thiourea, which produces reversible lung edema, also produces a transient increase in ACE activity in serum, lung lavage fluid, and pleural effusate (28). Similarly, rabbits with massive lung edema due to acute hyperoxic injury have increased ACE activity in lung lavage fluid (46).

The purpose of the present study was to determine the effect of pulmonary injury produced by kerosene aspiration on the pulmonary defense mechanisms responsible for clearing Staphylococcus aureus, and to evaluate the possible clinical usefulness of plasma ACE activity measurements as an adjunct in the prognostic assessment of the extent of lung injury in kerosene aspiration in children (28).

\section{MATERIALS AND METHODS}

Animals and hydrocarbon aspiration. Inbred DBA/IJ mice weighing 16-19 g were obtained from Jackson Laboratories (Bar Harbor, ME) and were kept at the facilities of our laboratory under standard conditions. Aspiration of kerosene (obtained from a common commercial source) was produced by the method described by Gerarde (20) for rats. Briefly, after weighing, each mouse was anesthetized with diethyl ether; a $0.12-\mathrm{mm}$ diameter catheter was passed through the mouth into the pharynx and 20 $\mu \mathrm{l}$ of kerosene were introduced. Immediately afterwards, the nares were occluded with the fingers until evident respiratory noises, produced by fluid aspiration, were heard. Animals from a control group were induced to aspirate $20 \mu \mathrm{l}$ of saline, as a methodologic control. Both groups of animals were kept for $24 \mathrm{~h}$ before the aerosol challenge. Mortality was zero and $4 \%$ for saline- and kerosene-treated animal groups respectively.

Determination of pulmonary clearance of bacteria. Kerosenetreated and control groups were placed in a nebulization chamber, built according to a design described previously (41). All animals were exposed for $30 \mathrm{~min}$ to an aerosol containing the challenge bacteria. Staphylococcus aureus ATCC 25923 was cultured in 12 $\mathrm{ml}$ of tryptic soy broth at $37^{\circ} \mathrm{C}$ and $400 \mathrm{rpm}$ in a shaker water bath. The bacteria were harvested in mid-log phase by centrifugation at $12,000 \times g$ for $10 \mathrm{~min}$ at $4^{\circ} \mathrm{C}$. The pellet was resuspended in saline to an optical density equivalent to $1 \times 10^{9} \mathrm{cfu}$ per $\mathrm{ml}$, and $10 \mathrm{ml}$ of this suspension were placed in the nebulizer. Animals were sacrificed either immediately after challenge $\left(t_{0}\right)$, or $4 \mathrm{~h}$ later $\left(\mathrm{t}_{4}\right)$, and the lungs carefully excised and rinsed externally with saline. Macroscopic features were recorded according to four categories: (I) no involvement (-), i.e., lungs of control mice with uniform pale pink color, without any macroscopic sign of abnormality; (2) mild involvement (+), i.e., lungs with clear signs of 
focal hemorrhages and/or consolidation in small patchy areas; (3) severe involvement $(++)$, i.e., lungs clearly affected with extensive areas of hemorrhages and/or consolidation, damaging more than an entire lobe; and (4) total or near total involvement $(+++)$, i.e., more than $95 \%$ of the lungs affected by hemorrhages and consolidation, leading to the death of the animal within $24 \mathrm{~h}$ after aspiration. Those lungs of category (3) were carefully dissected into damaged and normal-featured areas and weighed separately. The lung weight increase was recorded as the ratio of lung weight to body weight ( $\mathrm{Lw} / \mathrm{Bw})$ for each mouse. Lungs were homogenized separately in $5 \mathrm{ml}$ of ice cold distilled water with a PotterElvehjem tissue homogenizer (Thomas, Philadelphia, PA) and cultured quantitatively on tryptic soy agar. The results were recorded as the uncleared bacteria ratio, calculated as the ratio of cfu $\left(\mathrm{t}_{4} / \mathrm{t}_{\mathrm{o}}\right)$ of $S$. aureus.

Enzyme activity determination. Blood was obtained $24 \mathrm{~h}$ after kerosene (or saline) aspiration, immediately before the bacterial challenge. Blood was drawn from the retro-orbital venous sinus using heparinized $1.8-\mathrm{mm}$ diameter tubes. Plasma was separated and diluted 1:6 with $300 \mathrm{mM} \mathrm{NaCl}$, distributed into assay tubes and stored at $-70^{\circ} \mathrm{C}$ until the activity was measured. Plasma ACE (E.C. 3.4.15.1.) activity was determined by a modification of the original method described by Yang and Neff $(8)$. Briefly, $\left[{ }^{14} \mathrm{C}\right]$ hippuryl-L-histidyl-L-leucine $(3.1 \mathrm{mCi} / \mathrm{mmole}$, New England $\mathrm{Nu}$ clear, Boston, MA) was used as the substrate in an incubation medium containing $300 \mathrm{mM} \mathrm{NaCl}$. The $\left[{ }^{14} \mathrm{C}\right]$ hippuric acid released by enzymatic activity was extracted from the acidified medium by ethyl acetate and the radioactivity was measured by scintillation counting. Plasma ACE activity was expressed in units; one unit was defined as 1 nmole of hippuric acid generated per min, per $\mathrm{ml}$ of plasma at $37^{\circ} \mathrm{C}$.

Statistical analysis. Uncleared bacteria ratio was expressed as the arithmetic mean \pm S.E.M.; S.E.M. was calculated by the method of Wilks (57). Statistical analysis of UBR data was performed by applying the Mann-Whitney $U$ test for nonparametrics (48). Lung weight increases were tested for significance by the Student's $t$ test and linear regression was determined by least

Table 1. Induction of chemical pneumonitis by experimental

\begin{tabular}{lcccc}
\multicolumn{5}{c}{ kerosene aspiration } \\
Aspiration & $\begin{array}{c}\text { Gross ap- } \\
\text { Number of } \\
\text { animals }\end{array}$ & $\begin{array}{c}\text { pearance of } \\
\text { lungs }\end{array}$ & $\mathrm{Lw}^{1} \mathrm{Bw}^{2}\left(\times 10^{-3}\right)$ & $P^{3}$ \\
\hline No treat- & 12 & - & $5.85 \pm 0.12^{4}$ & \\
ment & & & & \\
Saline & 10 & - & $6.10 \pm 0.23$ & \\
Kerosene & 15 & + & $6.70 \pm 0.30$ & N.S. \\
Kerosene & 20 & ++ & $8.40 \pm 0.79$ & $<0.01$ \\
Kerosene & 5 & +++ & $14.52 \pm 1.39$ & $<0.01$ \\
\hline
\end{tabular}

\footnotetext{
${ }^{1}$ Macroscopic aspect of the lungs was recorded according to the definitions stated in "Materials and Methods."

${ }^{2} \mathrm{Lw} / \mathrm{Bw}$, lung weight/body weight.

${ }^{3}$ Significance level with respect to the group of saline-treated mice, calculated by Student's $t$-test.

${ }^{4}$ Arithmetic mean \pm S.E.M
}

squares (22). For all the performed tests, $P$ values lower than 0.05 were considered significant.

\section{RESULTS}

Mice were grouped in different categories according to the extent of macroscopic lung damage. The average $\mathrm{Lw} / \mathrm{Bw}$ value was calculated for each group and the results are shown in Table 1. Increase in lung weight has been recognized in experimental toxicology as a simple, objective gross measure of the extent of pulmonary injury $(20,58)$; therefore, the $\mathrm{Lw} / \mathrm{Bw}$ ratio was used as an index of pulmonary damage in the present study. The clinical signs that were observed in the kerosene-treated animals, compared to the saline-treated animals, were persistence of tachypnea, dyspnea, cyanosis, together with drowsiness, limitation of activity, lack of muscular coordination, and reluctance to take food and water for periods varying from minutes to several hours. Twenty-four hours after aspiration, all surviving animals (96\%) were apparently in good clinical condition and were then challenged with $S$. aureus. Bacterial counts at $\mathrm{t}_{\mathrm{o}}$ and $\mathrm{t}_{4}$, and UBR values are shown in Table 2. Mice with severe pneumonitis $(++)$ had significantly lower $(P<0.01)$ capacity to clear $S$. aureus than saline controls. In addition, the UBR correlated significantly $(P$ $<0.01, r=0.882$ ) with the extent of lung damage. It was noted that the deposition of $S$. aureus in lungs after exposure to the infective aerosol was decreased in animals with severe pneumonitis. In fact, a significant correlation was seen between the number of $S$. aureus cfu and the $\mathrm{Lw} / \mathrm{Bw}$ ratio (Fig. 1). In order to determine whether this effect was generalized, related to the whole lungs, or confined to the pneumonitis area, individual parts grossly affected by consolidation or hemorrhages were excised separately. The lung clearance of $S$. aureus was then determined for these parts and compared with the lung clearance of the apparently normal parts. Because the affected lungs were not homogeneously

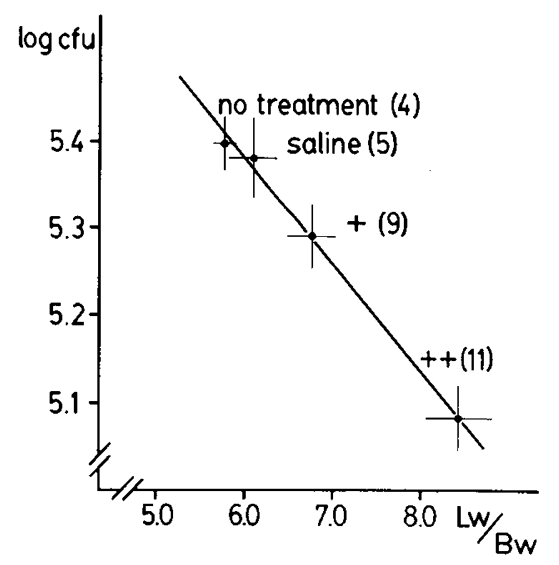

Fig. 1. Logarithm of the number of cfu of $S$. aureus deposited in mouse lungs as a function of the $\mathrm{Lw} / \mathrm{Bw}$ ratio. Mice were exposed for $30 \mathrm{~min}$ to the infective aerosol, $24 \mathrm{~h}$ after experimental aspiration of either kerosene or saline. Each point represents the arithmetic mean \pm S.E.M.; the quality of the animal group and sample size are indicated. The $\mathrm{Lw} / \mathrm{Bw}$ ratio is recorded $\times 10^{3}$. Regression was significant $(P<0.01)$ and $r=-0.992$.

Table 2. Pulmonary clearance of $S$. aureus in $D B A / 1 J$ mice with experimental kerosone aspiration

\begin{tabular}{lllll}
\hline \multicolumn{1}{c}{ Aspiration } & $\mathrm{cfu}\left(\mathrm{t}_{\mathrm{o}}\right) \times 10^{-5}$ & $\mathrm{cfu}\left(\mathrm{t}_{4}\right) \times 10^{-5}$ & $\mathrm{UBR}^{1}$ & $P^{2}$ \\
\hline No treatment & $2.45 \pm 0.23(4)^{3}$ & $0.58 \pm 0.05(6)$ & $0.24 \pm 0.02^{4}$ & \\
Saline & $2.51 \pm 0.22(5)$ & $0.61 \pm 0.04(5)$ & $0.24 \pm 0.03$ & \\
Kerosene (+) & $1.96 \pm 0.17(9)$ & $0.49 \pm 0.02(6)$ & $0.25 \pm 0.02$ & N.S. \\
Kerosene (++) & $1.22 \pm 0.10(11)$ & $0.54 \pm 0.09(9)$ & $0.44 \pm 0.05$ & $=0.004$ \\
\hline
\end{tabular}

${ }^{1}$ Uncleared bacteria ratio (UBR) is defined as cfu $\left(\mathrm{t}_{4}\right) / \mathrm{cfu}\left(\mathrm{t}_{0}\right)$.

${ }^{2}$ Significance level with respect to the group of saline-treated animals, calculated by Mann-Whitney's $U$ test.

${ }^{3}$ Arithmetic mean \pm S.E.M. (sample size).

${ }^{4}$ Arithmetic mean \pm S.E.M. calculated by the formula of Wilks. 
damaged by kerosene, resulting in affected zones of variable size from mouse to mouse, the tissue bacterial density was calculated for both types of zones. These results are given in Table 3 .

Damaged lung tissue contained significantly less cfu per $g$ than non-damaged tissue $(P=0.004)$. The differences in cfu density may well have been altered because of the increase in tissue weight due to severe lung edema; however, the clearance from the damaged zones was significantly lower $(P=0.029)$ whereas the clearance of $S$. aureus from the non-affected tissue was no different from that of saline controls. Preliminary experiments showed that the addition of $50 \mu \mathrm{l}$ of kerosene to $5 \mathrm{ml}$ of lung homogenate containing $2 \times 10^{5}$ cfu of $S$. aureus did not modify the viable counts (data not shown). We are confident, therefore, that the intrapulmonary killing of $S$. aureus was not due to direct toxicity of kerosene.

In order to confirm the correlation between lung clearance and lung damage, we used another method to quantitate the extent of lung damage. Plasma ACE activity was determined $24 \mathrm{~h}$ after kerosene aspiration. Enzyme activity was decreased in animals with severe pneumonitis and correlated with $\mathrm{Lw} / \mathrm{Bw}$ ratio (Fig. 2), suggesting an inverse relationship between plasma ACE activity and the severity of the necrotizing pneumonitis. There appeared to be some correlation between lung capacity to clear $S$. aureus and plasma ACE activity (Fig. 3); regression was not linear and did not become linear by logarithmic transformation of ACE activity values.

Table 3. Pulmonary clearance of $S$. aureus in different regions of murine lungs with kerosene-induced pneumonitis

\begin{tabular}{lccc}
\hline & \multicolumn{2}{c}{ Bacterial density $\left(\mathrm{cfu} / \mathrm{g} \times 10^{-5}\right)$} & $\begin{array}{c}\text { Local lung clear- } \\
\text { ance (uncleared } \\
\text { bacteria ratio) }\end{array}$ \\
\cline { 2 - 4 } & $\mathrm{t}_{0}$ (range) & $\mathrm{t}_{4}$ (range) & $0.82 \pm 0.34^{2}$ \\
\hline Affected region $^{1}$ & $0.86-5.74$ & $0.65-7.32$ & $0.24 \pm 0.10$ \\
$\begin{array}{c}\text { Non-affected re- } \\
\text { gion }\end{array}$ & $6.84-17.11$ & $1.04-6.97$ & $=0.029$ \\
$p^{3}$ & $=0.004$ & $=0.343$ (N.S.) & 4 \\
Sample size & 5 & 4 & 4
\end{tabular}

${ }^{1}$ Macroscopically affected regions were excised and homogenized separately; affected regions were those clearly involved with kerosene pneumonitis.

${ }^{2}$ Arithmetic mean \pm S.E.M. calculated from bacterial density values by the Wilks' formula.

${ }^{3}$ Significance level for the comparison between affected and non-affected regions, calculated by the Mann-Whitney's $U$ test.

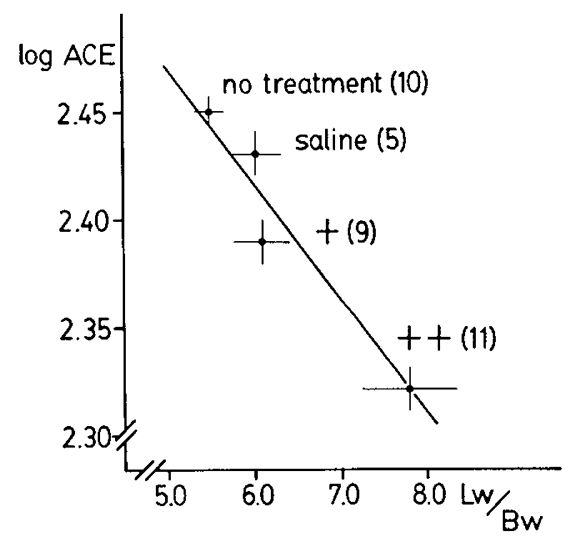

Fig. 2. Logarithm of plasma angiotensin-converting enzyme (ACE) activity (units, see definition in "Materials and Methods") as a function of $\mathrm{Lw} / \mathrm{Bw}$ ratio in mice $24 \mathrm{~h}$ after kerosene or saline aspiration. Each point represents the arithmetic mean \pm S.E.M.; the quality of the animal group and sample size are indicated. The $\mathrm{Lw} / \mathrm{Bw}$ ratio is recorded $\times 10^{3}$. Regression was significant $(P<0.01)$ and $r=-0.931$.

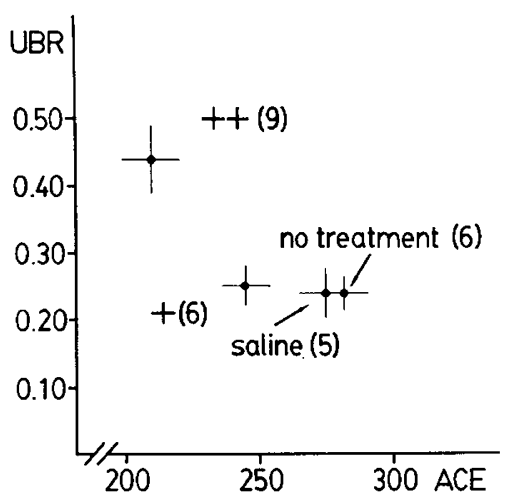

Fig. 3. Uncleared bacteria ratio (UBR) as a function of plasma angiotensin-converting enzyme (ACE) activity (in units) in mice following kerosene or saline aspiration, and untreated controls. Each point represents the arithmetic mean \pm S.E.M. The quality of the animal group and sample size are indicated.

\section{DISCUSSION}

Different hypotheses have been proposed regarding the route through which petroleum products reach the lungs. Many workers support direct aspiration during ingestion or subsequent vomiting, either spontaneous or induced $(10,13,16,19,32,44,56,58)$ whereas others favor gastrointestinal absorption $(2,12,52)$. Because hydrocarbons are lipid solvents, cell membrane disruption $(2,35)$ has been proposed as mechanism for cell injury. Giammona (21) suggested that the primary lung injury may be due to interaction between the hydrocarbon and pulmonary surfactant. This would lead to alveolar instability, collapse and early distal airway closure. Furthermore, electron microscopic examination of alveolar macrophages revealed toxic granulations $24 \mathrm{~h}$ after insult (14). The extent of lung damage may determine the prognosis for the patient (52) and in severe cases death may occur within the first $24 \mathrm{~h}(30,36,47)$. Patients who survive the initial period often recover in a matter of days and occasionally weeks, usually without clinical or radiologic sequelae. But a secondary bacterial infection may supervene resulting in prolongation of respiratory symptoms and possibly contribute to complications $(1,5,10,36$, 53). It is possible that hydrocarbons may impair lung defenses against bacterial infections; however, to our knowledge, this has not been studied in human beings and only to a limited extent in animals (6). In the present study we have investigated the effect of experimentally induced kerosene pneumonitis on the lung clearance of $S$. aureus. We chose kerosene as a representative hydrocarbon because it is found in many household products, and is often associated with intoxication in children $(23,42)$.

Early lung clearance of $S$. aureus is effected almost exclusively by the normal cell population of the lower respiratory tract, namely alveolar macrophages (24). For the purpose of the present investigation we used $S$. aureus as the challenge microorganism because infection with gram positive cocci is believed to be one of the most common complications in intoxicated patients (23), and because of the technical advantages associated with the use of this bacterial species (45). Different experimental conditions as well as chemical products can decrease the capacity of the lung to clear bacteria (26). In fact, kerosene ingestion in mice, at a dose of 10 $\mathrm{ml} / \mathrm{kg}$ (equivalent to a $20-\mathrm{kg}$ child ingesting $200 \mathrm{ml}$ of kerosene), produces chemical pneumonitis, with significant decrease in lung clearance of $S$. aureus (6). A dose of $0.25 \mathrm{ml} / \mathrm{kg}$ of kerosene in rabbits (comparable to the same child aspirating only one spoonful) produces death within $60 \mathrm{~h}(44)$. The method used in this work to provoke fluid aspiration allowed us to obtain different degrees of lung damage. If the animals had aspirated the whole volume delivered, they would have received a dose equivalent to aspiration of $20 \mathrm{ml}$ by a $20-\mathrm{kg}$ child. 
Extensive damage of the lungs was seen $24 \mathrm{~h}$ after kerosene aspiration in DBA/1J mice; the degree of damage had significant correlation with $\mathrm{LW} / \mathrm{Bw}$ ratio, plasma ACE activity and pulmonary clearance of $S$. aureus. The capacity of the lungs to eliminate $S$. aureus in those sections without any macroscopic abnormality was no different from lungs of control animals; however, clearance was dramatically impaired in those sections obviously affected by kerosene aspiration. One possible explanation for this fact is that necrotic pulmonary tissue loses most of its capacity to clear $S$. aureus and may also provide appropriate surfaces for bacterial adherence and duplication.

Although many physicians used prophylactic antibiotic therapy routinely in hydrocarbon ingestion $(1,10,16,27,49)$, there is still some controversy concerning its efficacy $(4,13,51)$. Eade et al. (14) advocate its use only in patients compromised by malnutrition, underlying pulmonary disease or coma. Corticosteroids, although widely used in the past in the treatment of hydrocarbon pneumonitis (31), are no longer recommended; recent reports have shown that this treatment is not only unsuccessful $(4,13,51)$ but also can further decrease lung clearance of bacteria (25).

Patients with chronic obstructive pulmonary diseases, lung cancer, tuberculosis, chronic asthma and cystic fibrosis have significantly lower serum ACE activity (33). There is no explanation for the decrease in plasma ACE activity in these patients, although the loss of functional lung tissue cannot be discounted. In the present study, kerosene aspiration produced a decrease in plasma ACE activity, correlating with the extent of lung damage (Lw/ Bw ratio) and lung clearance of $S$. aureus. These results suggest that necrosis of the affected tissue might account for the decrease in plasma ACE activity. Furthermore, the depletion of ACE from lung vessel endothelium soon after injury might also be an explanation for the plasma ACE activity decrease $24 \mathrm{~h}$ after kerosene aspiration.

In conclusion, we have studied the effects of acute kerosene aspiration in a mouse model system. Our data show that there is an impairment in lung clearance of $S$. aureus, which correlates with the severity of chemical pneumonitis. Further investigation involving children with hydrocarbon aspiration is needed to ascertain the validity of using plasma ACE activity as a useful indicator of lung endothelial injury and a prognostic aid in chemical pneumonitis.

\section{REFERENCES AND NOTES}

1. Arena, J.: Poisoning. p. 222 (Charles Thomas Publisher, Springfield, IL, 1979).

2. Ashkenazi, A. E. and Berman, S. E.: Experimental kerosene poisoning in rats. Pediatrics, 28: 642 (1961).

3. Blattner, R. J.: Kerosene poisoning. J. Pediatr., 39: 391 (1951).

4. Brown, J., Burke, B., and Dajani, A.: Experimental kerosene pneumonia: evaluation of some therapeutic regimens. J. Pediatr., 84: 396 (1974)

5. Brünner, S., Rovsing, H., and Wulf, H.: Roentgenographic changes in the lungs of children with kerosene poisoning. Am. Rev. Respir. Dis., 89: 250 (1954)

6. Burley, S. and Huber, G.: The effect of toxic agents commonly ingested by children on antibacterial defenses in lungs. Pediatr. Res., 5: 405 (1971).

7. Cachia, E. A. and Fenech, F. F.: Kerosene poisoning in children. Dis. Child., 39: 502 (1964).

8. Chevillard, C. and Saavedra, J. M.: High angiotensin-converting enzyme activity in the neurohypophysis of Brattleboro rats. Science, 216: 646 (1982).

9. Coruh, M. and Inal, $H$.: Kerosene poisoning in children with special reference to lung complications. Turk. J. Pediatr., 8: 39 (1966).

10. Daeschner Jr., C. W., Blattner, R. J., and Collins, V. P.: Hydrocarbon pneumonitis. Pediatr. Clin. N. Amer., Feb: 243 (1957).

11. Deeths, T. M. and Breeden, J. T.: Poisoning in children-a statistical study of 1,057 cases. J. Pediatr., 78: 299 (1971).

12. Deichmann, W. H., Kitsmiller, K. V., Witherup, S., and Johansmann, R.: Kerosene intoxication. Ann. Int. Med., 21: 803 (1944).

13. Dice, W. H., Ward, G., Kelly, J., and Kilpatrick, W. R.: Pulmonary toxicity following the gastrointestinal ingestion of kerosene. Ann. Emergen. Med., 11: 138 (1982).

14. Eade, N. R., Taussig, L., and Marks, M. I.: Hydrocarbon pneumonitis. Pediatrics, 54: 351 (1974)

15. El-Habashi, A., Fahim, A., and Kamel, A.: Toxi-pathological studies in kerosene. J. Egyp. Med. Ass., 52: 421 (1969)

16. Foley, J. C., Dreyer, N. B., Soules Jr., A. B., and Woll, E.: Kerosene poisoning in young children. Radiology, 62: 817 (1954)

17. Fow, M.: Personal communication, (1982).

18. Fow, M.: Tabulations of 1979 poison control reports. Bulletin of National
Clearinghouse for Poison Control Centers, 25: 1 (1981)

19. Gerarde, H. W.: Toxicological studies on hydrocarbons. V. Kerosene. Toxicol Appl. Physiol., 1: 462 (1959).

20. Gerarde, H. W.: Toxicological studies on hydrocarbons. IX. The aspiration hazard and toxicity of hydrocarbons and hydrocarbon mixture. Arch. Environ. Health., 6: 392 (1963).

21. Giammona, S.: The effects of furniture polish on pulmonary surfactant. Am. J. Dis. Child., 113: 659 (1967).

22. Goldstein, A.: Correlation. In: Biostatistics. p. 129 (The Macmillan Co., New York, NY, 1962).

23. Gosselin, R. E., Hodge, H. C., Smith, R. P., and Gleason, M. N.: Clinical toxicology of commercial products-acute poisoning. p. 72 (Williams \& Wilkins, Baltimore, MD, 1976).

24. Green, G. M. and Kass, E. H.: The role of the alveolar macrophage in the clearance of bacteria from the lung. J. Exp. Med., 119: 167 (1964).

25. Green, G. M. and Kass, E. H.: Factors influencing the clearance of bacteria by the lung. J. Clin. Invest., 43: 769 (1964).

26. Green, G. M., Jakab, G. J., Low, R. B., and Davis, G. S.: State of the Art. Defense mechanisms of the respiratory membrane. Am. Rev. Respir. Dis., 115: 479 (1977).

27. Griffin, J. W., Daeschner, C. W., Collins, V. P., and Eaton, W. L.: Hydrocarbon pneumonitis following furniture polish ingestion. J. Pediatr., 45: 13 (1954).

28. Hollinger, M. A., Giri, S. N., Patwell, S., Zuckerman, J. E., Gorin, A., and Parsons, P.: Effects of acute lung injury on angiotensin-converting enzyme in serum, lung lavage and effusate. Am. Rev. Respir. Dis., 121: 373 (1980).

29. Huxtable, K. A., Bolande, R. P., and Klaus, M.: Experimental furniture polish pneumonia in rats. Pediatrics, 34: 228 (1964).

30. Jacobziner, H. and Raybin, H. W.: Kerosene and other petroleum distillate poisoning. NY State J. Med., 63: 3428 (1963).

31. Jamison, K., and Wallance, E. R.: Kerosene pneumonitis treated with adrenal steroids. Calif. Med. J., 100: 1 (1964).

32. Lesser, L. I., Ween, H. S., and McKay, J. D.: Pulmonary manifestations following ingestion of kerosene. J. Pediatr., 23: 352 (1943).

33. Lieberman, $J .:$ Elevation of serum angiotensin-converting enzyme (ACE) level in sarcoidosis. Am. J. Med., 59: 361 (1975)

34. McDonald, R.: Accidental poisoning in children in Cape Town, with special reference to kerosene and salicylates. South Afr. Med. J., 35: 21 (1961).

35. Mellin, R. B.: Lung injury from hydrocarbon aspiration and smoke inhalation. In: Kendig Jr., E. L., and Chernik, V.: Disorders of the respiratory tract in children. p. 491 (W. B. Saunders \& Co., Philadelphia, PA., 1977).

36. Mintz, A. A.: Furniture polish intoxication. South Med. J., 59: 1010 (1966).

37. Morrison, I., and Sprague, P.: Kerosene poisoning. Aust. Radiol., 20: 118 (1976).

38. Narasimhan, M. J. and Ganla, V. G.: Experimental studies on kerosene poisoning. Acta Pharm. Toxicol., 25: 214 (1967).

39. Nouri, L. and Al-Rahim, K.: Kerosene poisoning in children. Postgrad. Med. J., 46: 71 (1970).

40. Pelfort, G., Cassinelli, J. F., and Portillo, J. M.: Neuropatías por ingestión de kerosene o bencina en el nin̄o. Arch. Pediatr. Uruguay, 15: 557 (1944).

41. Pivetta, O. H., Sordelli, D. O., and Labal, M. L.: Pulmonary clearance of Staphylococcus aureus in mutant mice with some hereditary alterations resembling cystic fibrosis. Pediatr. Res., 11: 1133 (1977).

42. Press, E.: Co-operative kerosene poisoning study. Pediatrics, 29: 648 (1962).

43. Raymond, C., Ng, R., Darwish, H., and Stewart, D. A.: Emergency treatment of petroleum distillate and turpentine ingestion. Can. Med. J., 21: 537 (1974).

44. Richardson, J. A. and Pratt-Thomas, H. R.: Toxic effects of varying doses of kerosene administered by different routes. Am. J. Med. Sci., 221: 531 (1951).

45. Ruppert, D., Jakab, G. J., Sylwester, D. L., and Green, G. M.: Sources of variance in the measurement of intrapulmonary killing of bacteria. J. Lab. Clin. Med., 87: 544 (1976).

46. Shasby, D. M., Shasby, S. S., Bowman, C. M., Fox, R. B., Harada, R. M., Tate, R. M., and Repine, J. E.: Angiotensin converting enzyme concentrations in lung lavage of normal rabbits and rabbits treated with nitrogen mustard exposed to hyperoxia. Am. Rev. Respir. Dis., 124: 202 (1981).

47. Shirky, H. C.: Treatment of petroleum distillate ingestion. Mod. Treatment, 4: 697 (1967).

48. Siegel, S.: Nonparametrics statistics for the behavioral sciences. p. 116 (McGrawHill Book Co.-Kogakusha Co. Ltd., Tokyo, 1956).

49. Soule, A. B. and Foley, S. C.: Poisoning from petroleum distillates: The hazards of kerosene and furniture polish. J. Maine Med. Assoc., 48: 103 (1957).

50. Southby, R.: Fatal poisoning under five years of age. Med. J. Aust., 1: 533 (1965).

51. Steele, R. W., Conklin, R. H., and Mark, H. M.: Corticosteroids and antibiotics for the treatment of fulminant hydrocarbon aspiration. J. Am. Med. Assoc., 219: 1434 (1972).

52. Steiner, M. M.: Syndrome of kerosene poisoning in children. Am. J. Dis. Child., 74: 32 (1947).

53. Stern, R. C.: Hydrocarbon pneumonia. In: Vaughan, B. C., McKay, R. J., and Behrman, R. E.: Nelson Textbook of Pediatrics. p. 1217 (W. B. Saunders \& Co., Philadelphia, PA, 1979).

54. Vaccaro, R. and Genova, R.: Investigation of pulmonary cytology by means of needle biopsy in bronchopneumonia caused by petroleum. Minerva Pediatr., 16: 853 (1964).

55. Valvert, J., Lorent, J. P., and Kalapos, I.: Intoxication by oral ingestion of petroleum derivatives. Eur. J. Toxicol., 6: 292 (1973).

56. Waring, J. I.: Pneumonia in kerosene poisoning. Am. J. Med. Sci., 186: 325 (1933).

57. Wilks, S. S.: Mathematical statistics. p. 260 (John Wiley \& Sons, New York N. Y., 1962). 
58. Wolfsdorf, J. and Kundig, H.: Kerosene poisoning in primates. South Afr. Med. 61. Dr. Nouri is on sabbatical leave from the Department of Pediatrics, University J., 46: 619 (1972).

59. Wolfsdorf, J.: Experimental kerosene pneumonitis in primates: relevance to the therapeutic management of childhood poisoning. Clin. Exp. Pharm. Physiol., 3: 539 (1976)

60. Requests for reprints should be addressed to: Dr. L. Nouri, Medical City Hospital, Baghdad, Iraq. of Baghdad, Iraq.

62. Dr. Sordelli is a fellow supported by "Consejo Nacional de Investigaciones Cientificas y Tecnicas (CONICET)," Buenos Aires, Argentina.

63. Received for publication August 3,1982.

64. Accepted for publication December 14, 1982. 